\title{
Quality Control of Product: Statistical Process Control
}

\author{
Solehatin Ika Putri, Chandra Budhi Septyandi, Dwi Phayana Rohandani \\ Magister Management, School of Postgraduate \\ Universitas Pendidikan Indonesia \\ solehatin.ikaputri@student.upi.edu
}

\begin{abstract}
PT. Wahana Java Semesta Intermedia are still the emergence of defect products in every production and it escaped from quality control checked thus it reaches the consumer. This study aimed to analyze the application of products quality control system applied in PT. Wahana Java Semesta Intermedia, Radar Banten Newspaper products whether it is well within the control or not and looking for the factors that causing to the defect products. Data collection and information obtained from interviews and documentation for the number of products and production defects for three months in PT. Wahana Java Semesta Intermedia. The methods used to analyze products quality control by using statistical process control and fishbone diagram to determine the cause of defects products. Results showed that products quality control in PT. Wahana Java Semesta Intermedia is still controlled by the largest type of defects that is blurred ink with defects percentage $59.79 \%$ and with $1.26 \%$ percentage of defects from amount of checked production. Factors causing defects products are human, machine, work methods, environment and materials, in this case human is the primary cause of defects products.
\end{abstract}

\section{Keywords-Quality Control, SPC, Fishbone Diagram}

\section{INTRODUCTION}

A good business event if in manufacturing or service cannot be separated from the consumer and the product. Along the advances information and technology today, the company is required to face consumers who are increasingly sensitive to the quality of goods or services that they wish to consume. To face this condition the company must pay attention to the quality of its products and intensified to produce quality of goods or services, so that the product can be accepted by consumers and competence in the market with the other products.

The company's quality control is necessary needed, by producing the customer's needs the company will attract consumers to buy the company's products in fulfilling their needs. So that from the consumer buying company can increase profits.

Many methods can be used to control the quality with each characteristic. Using Statistical Process Control (SPC) in quality control means quality is controlled from the beginning of production process, during the production process until the finished products. Before products will sell, the products have been examined then the good products will be separated with the defect products so that total product will decrease.

One of SPC tools is control chart and depend on one research say that it is not easy to successfully implement effective and sustainable control methods. The control chart is one commonly used tool in the measure and control phase. Control charts can also act as a means of organizational learning [1]. In other hand, the review about paradigm shift in types of SPC control chart does show clearly that the application boundaries extend considerably beyond manufacturing and that the range of problems to which SPC control chart techniques can be applied are much wider than commonly assumed. The paper has highlighted the critical fundamental and technical issues which need to be addressed with non-standard SPC chart applications [2].

Statistical quality control can detect errors or irregularities statistically [3]. SPC has the potential to improve the quality of maintenance, delivery process and ultimately the safety of patients or customers [4]. The application of statistical tools such as control charts, histogram, caused and effect diagram along with process capability analysis is presented in the study to eliminate quality problems arising out of various assignable causes during machining of crankcase. It is observed from the study that when the special or assignable causes of variation are present in manufacturing, the process is deemed to be outof-control then use of SPC [5]. Depend on this view in this research SPC will use for knowing the condition of quality control.

Large and small companies realized the importance of quality, but each company has a different view on the implementation of quality control. PT. Wahana Java Semesta Intermedia is one company of newspaper printing in Serang Banten, where market covering the area of Banten Province and with one of product named Radar Banten. As one of big company in Banten and has large market coverage in Banten Province, they need a system of quality control for increase consumer loyalty to the Radar Banten newspaper. The quality of the newspaper is not only on paper forms (that are not defects such as blurred, cropped and so on), but also the quality of advertising services corresponding to customer orders and the quality of the news on Radar Banten newspaper. PT. Wahana Java Semesta Intermedia (Radar Banten) has understood well for the importance of quality.

In the fact for Radar Banten, there are still defect newspapers product that escaped from quality control checked thus it reaches the consumer. As noted by some consumers Radar Banten based on interviews in March 2013. Some consumers of Radar Banten newspaper still often found defect product of Radar Banten newspaper, there is some unclear writing caused blurred ink on the paper. In addition, there are several mistyping errors and patches of ink around the printed Radar Banten newspapers. In other cases, the newspaper layout found in wrong accurate position and some of the pictures were cropped. Based on interviews with department of production, type of defect newspaper most often found are paper cut not on its part, blurred ink on the text and dirty patches when printing process. If the consumers reach defects products, it will impact to decreasing consumer trust to Radar Banten newspaper.

The problems that will be discussed in this research are:

- Does the implementation of quality control in PT. Wahana Java Semesta Intermedia (Radar Banten) are under control limits. 
- What factors are causing in the implementation of quality control in PT. Wahana Java Semesta Intermedia (Radar Banten).

The purposes of this study are:

- To analyze the implementation of quality control in PT. Wahana Java Semesta Intermedia (Radar Banten) in an attempt to determine if the defects products are under control or outside the control limit.

- To identify any factors that cause in the implementation of quality control on products manufactured by PT. Wahana Java Semesta Intermedia (Radar Banten).

\section{THEORETICAL BASIS}

Quality control is technique and planned activities or actions undertaken to achieve, maintain and improve the quality of products and services to comply with predetermined standard and could meet customer satisfaction. The main objective the implementation of quality control is to get a guarantee that the quality of the products or services produced in accordance with the quality standards have been established and in accordance with the desire consumers by the most optimal cost [6].

Accurate and valid data will we got as well for the analysis by using seven tools. The main statistical tools can be used as tools for quality control, which is; check Sheet, histogram, control chart, Pareto diagram, causal diagram, scatter diagram, and process diagram. Before that we must know that Statistical Process Control is a statistical technique used to determine the condition of quality product, SPC widely used to ensure that the process match with standards so that the products also have a good quality [7]. In other words, Statistical Process Control is a process used to monitor the standards, create a measuring and take corrective action while a product or service being produced.

The framework used in this study illustrates how quality control using statistic can analyze the degree of defects product which produced by PT. Wahana Java Semesta Intermedia (Radar Banten) that over the tolerance limit, after that identify the cause of such problems and the last make suggestions or recommendations for improvement of quality in the future. Based on the theoretical basis and previous research, we can make frameworks in this study.

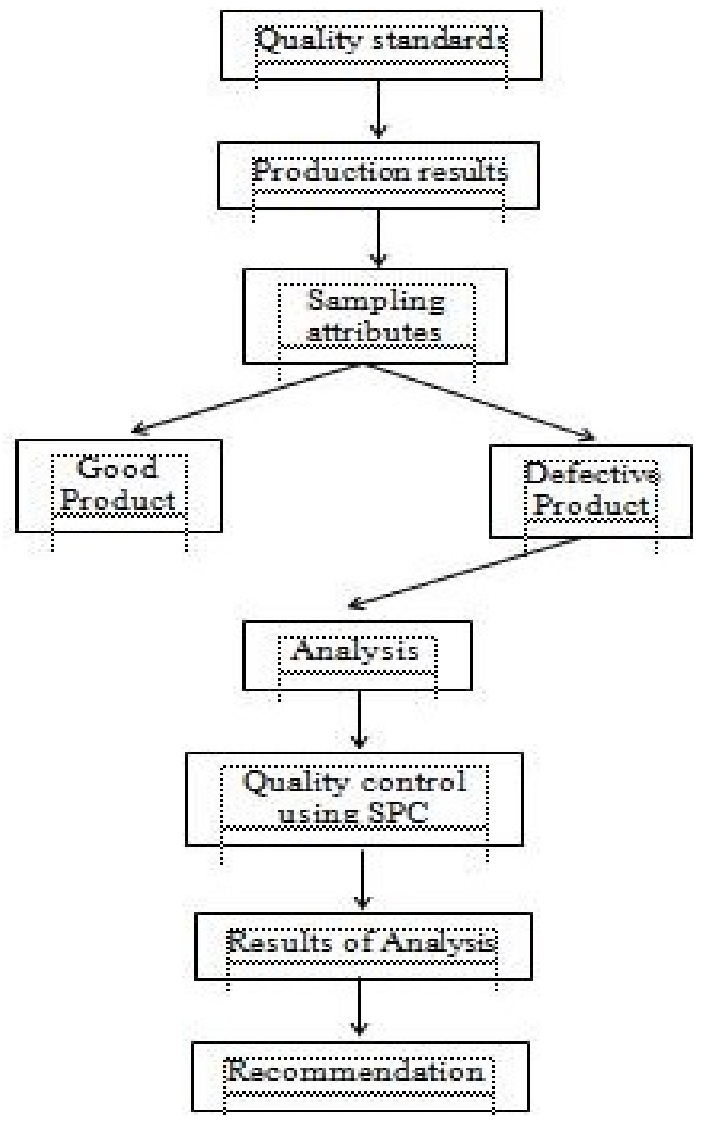

Fig. 1. Research Framework

\section{RESEARCH METHODS}

The variable of this research is quality control, in which the quality control problem is a problem that can't be measured directly and need detailed indicators to be measure clearly. Thus the problem of quality control is a latent variable. Latent variable is a formation variable or hidden variables that must be declared by using an indicator. Another name for the latent variable is a factor, construct, or unobserved variable [8]. The indicators regarding quality control in this study is the number of defective products, the number of samples.

The population and the sample in this study is the number of Radar Banten newspaper produced by PT. Wahana Java Semesta Intermedia during the three months from January to March 2013. Data used in this study consisted of secondary data about the number of production, product defect and the number of samples. There are also primary 


\section{Arnumis PRESS}

data based on interviews to employees and customers of PT. Wahana Java Semesta Intermedia. Data obtained is quantitative and most of the data obtained from the company that became a place of research. Quantitative data in few articles mentioned such as numerical data in spreadsheets, databases or log files, and only a handful discuss quantitative data above and beyond aggregate usage statistics [9]. Quantitative data in this research obtained from the interviews and the document / records of the production and the quality control department.

\section{RESULTS AND DISCUSSIONS}

Quality control of finished product is done through the inspection. In general, the characteristics of good quality standard for newspapers are clean, flat ink absorption (the prints are not blurred), the edges of the paper cut according to the machine settings.

The first step taken to analyze statistical quality control is to create a table (check sheet) production quantities and product defect / incompatible with quality standards.

TABle I. Radar Banten Newspaper Total Production January 2013

\begin{tabular}{|c|c|c|c|c|c|}
\hline \multirow{3}{*}{ Date } & \multirow{3}{*}{$\begin{array}{c}\text { Print } \\
\begin{array}{c}\text { Circulation } \\
\text { (Copy) }\end{array}\end{array}$} & \multirow{2}{*}{\multicolumn{3}{|c|}{ Type of Defects (Copy) }} & \multirow{3}{*}{\begin{tabular}{|c|} 
Total \\
\\
Defects \\
(Copy)
\end{tabular}} \\
\hline & & & & & \\
\hline & & Dirty Patches & Blurred & Cropped & \\
\hline 1 & 0 & 0 & 0 & 0 & 0 \\
\hline 2 & 20516 & 52 & 119 & 30 & 201 \\
\hline 3 & 20500 & 62 & 150 & 38 & 250 \\
\hline 4 & 20330 & 51 & 119 & 32 & 202 \\
\hline 5 & 29430 & 41 & 90 & 26 & 157 \\
\hline 6 & 15090 & 31 & 75 & 19 & 125 \\
\hline 7 & 20645 & 52 & 121 & 30 & 203 \\
\hline 8 & 20824 & 63 & 149 & 38 & 250 \\
\hline 9 & 20910 & 56 & 119 & 33 & 208 \\
\hline 10 & 20855 & 88 & 210 & 53 & 351 \\
\hline 11 & 20885 & 50 & 120 & 30 & 200 \\
\hline 12 & 20359 & 67 & 149 & 39 & 255 \\
\hline 13 & 15100 & 62 & 151 & 38 & 251 \\
\hline 14 & 31440 & 55 & 132 & 33 & 220 \\
\hline 15 & 31170 & 60 & 144 & 36 & 240 \\
\hline 16 & 31145 & 52 & 122 & 30 & 204 \\
\hline 17 & 20859 & 65 & 156 & 39 & 260 \\
\hline 18 & 31163 & 50 & 120 & 30 & 200 \\
\hline 19 & 20250 & 70 & 168 & 42 & 280 \\
\hline 20 & 15080 & 62 & 150 & 38 & 250 \\
\hline 21 & 31013 & 78 & 189 & 47 & 314 \\
\hline 22 & 31320 & 53 & 121 & 30 & 204 \\
\hline 23 & 20916 & 82 & 198 & 50 & 330 \\
\hline 24 & 0 & 0 & 0 & 0 & 0 \\
\hline 25 & 20830 & 68 & 162 & 41 & 271 \\
\hline 26 & 20240 & 48 & 114 & 29 & 191 \\
\hline 27 & 15571 & 66 & 158 & 39 & 263 \\
\hline 28 & 20923 & 75 & 180 & 45 & 300 \\
\hline 29 & 31030 & 88 & 210 & 53 & 351 \\
\hline 30 & 20790 & 50 & 118 & 30 & 198 \\
\hline 31 & 20750 & 113 & 270 & 67 & 450 \\
\hline Total & 659934 & 1810 & 4284 & 1085 & 7179 \\
\hline Average & 22756 & 63 & 148 & 37 & 248 \\
\hline
\end{tabular}

a. Source: PT. Wahana Java Semesta Intermedia, 2013

TABle II. Radar Banten Newspaper Total Production FEBRUARY 2013

\begin{tabular}{|c|c|c|c|c|c|}
\hline \multirow{2}{*}{ Date } & \multirow{2}{*}{$\begin{array}{c}\text { Print } \\
\text { Circulation } \\
\text { (Copy) }\end{array}$} & \multicolumn{2}{|c|}{ Type of Defects (Copy) } & Total \\
\cline { 3 - 5 } & Defects & Patches & Blurred & Cropped & $\begin{array}{c}\text { Depy) } \\
\text { (Copy) }\end{array}$ \\
\hline 1 & 20760 & 63 & 150 & 38 & 251 \\
\hline
\end{tabular}

\begin{tabular}{|c|c|c|c|c|c|}
\hline 2 & 29923 & 78 & 186 & 47 & 311 \\
\hline 3 & 15070 & 6 & 15 & 4 & 25 \\
\hline 4 & 20948 & 18 & 42 & 11 & 71 \\
\hline 5 & 31094 & 88 & 209 & 53 & 350 \\
\hline 6 & 20722 & 113 & 270 & 68 & 451 \\
\hline 7 & 20690 & 83 & 197 & 50 & 330 \\
\hline 8 & 22915 & 55 & 132 & 33 & 220 \\
\hline 9 & 19860 & 70 & 168 & 42 & 280 \\
\hline 10 & 0 & 0 & 0 & 0 & 0 \\
\hline 11 & 31340 & 54 & 130 & 33 & 217 \\
\hline 12 & 20540 & 56 & 138 & 35 & 229 \\
\hline 13 & 31193 & 78 & 186 & 47 & 311 \\
\hline 14 & 20995 & 98 & 234 & 59 & 391 \\
\hline 15 & 20776 & 80 & 192 & 48 & 320 \\
\hline 16 & 29890 & 108 & 257 & 65 & 430 \\
\hline 17 & 14926 & 81 & 195 & 49 & 325 \\
\hline 18 & 20943 & 73 & 174 & 44 & 291 \\
\hline 19 & 20789 & 93 & 221 & 56 & 370 \\
\hline 20 & 20888 & 95 & 228 & 57 & 380 \\
\hline 21 & 31067 & 105 & 252 & 63 & 420 \\
\hline 22 & 31036 & 112 & 266 & 68 & 446 \\
\hline 23 & 19869 & 138 & 329 & 83 & 550 \\
\hline 24 & 15107 & 87 & 210 & 53 & 350 \\
\hline 25 & 25798 & 75 & 179 & 45 & 299 \\
\hline 26 & 14745 & 62 & 149 & 38 & 249 \\
\hline 27 & 21905 & 90 & 216 & 54 & 360 \\
\hline 28 & 31186 & 73 & 175 & 44 & 292 \\
\hline Total & 624975 & 2132 & 5100 & 1287 & 8519 \\
\hline Average & 23147 & 79 & 189 & 48 & 316 \\
\hline
\end{tabular}

TABLE III. RAdar Banten Newspaper Total Production March 2013

\begin{tabular}{|c|c|c|c|c|c|}
\hline \multirow{2}{*}{ Date } & \multirow{2}{*}{$\begin{array}{c}\text { Print } \\
\text { Circulation } \\
\text { (Copy) }\end{array}$} & \multicolumn{3}{|c|}{ Type of Defecrs(Copy) } & \multirow{2}{*}{$\begin{array}{c}\text { Total } \\
\text { Defects } \\
\text { (Copy) }\end{array}$} \\
\hline & & Dirty Patches & Blurred & Cropped & \\
\hline 1 & 34400 & 74 & 169 & 43 & 286 \\
\hline 2 & 29544 & 65 & 156 & 39 & 260 \\
\hline 3 & 15060 & 81 & 195 & 49 & 325 \\
\hline 4 & 30630 & 83 & 198 & 50 & 331 \\
\hline 5 & 30805 & 75 & 180 & 45 & 300 \\
\hline 6 & 30946 & 95 & 228 & 57 & 380 \\
\hline 7 & 20740 & 90 & 216 & 54 & 360 \\
\hline 8 & 30835 & 98 & 239 & 60 & 397 \\
\hline 9 & 29865 & 143 & 342 & 86 & 571 \\
\hline 10 & 14857 & 88 & 210 & 53 & 351 \\
\hline 11 & 25830 & 70 & 168 & 42 & 280 \\
\hline 12 & 0 & 0 & 0 & 0 & 0 \\
\hline 13 & 31082 & 68 & 162 & 41 & 271 \\
\hline 14 & 31010 & 95 & 228 & 57 & 380 \\
\hline 15 & 31035 & 130 & 312 & 78 & 520 \\
\hline 16 & 30200 & 83 & 198 & 50 & 331 \\
\hline 17 & 14860 & 72 & 173 & 43 & 288 \\
\hline 18 & 31179 & 77 & 179 & 49 & 305 \\
\hline 19 & 31264 & 113 & 269 & 68 & 450 \\
\hline 20 & 31090 & 98 & 234 & 59 & 391 \\
\hline 21 & 31228 & 78 & 191 & 49 & 318 \\
\hline 22 & 32970 & 97 & 229 & 56 & 382 \\
\hline 23 & 30028 & 93 & 221 & 58 & 372 \\
\hline 24 & 14940 & 125 & 299 & 75 & 499 \\
\hline 25 & 31141 & 83 & 197 & 53 & 333 \\
\hline 26 & 31187 & 103 & 246 & 62 & 411 \\
\hline 27 & 32345 & 98 & 240 & 61 & 399 \\
\hline 28 & 31305 & 83 & 195 & 55 & 333 \\
\hline 29 & 0 & 0 & 0 & 0 & 0 \\
\hline 30 & 30170 & 95 & 228 & 57 & 380 \\
\hline 31 & 14924 & 135 & 323 & 81 & 539 \\
\hline Total & 805470 & 2688 & 6425 & 1630 & 10743 \\
\hline Average & 27775 & 93 & 222 & 53 & 370 \\
\hline
\end{tabular}

Source: PT. Wahana Java Semesta Intermedia, 2013

After check sheet is done, next step is to create a histogram. The histogram is useful fatherly see what kind of the most common defects. 


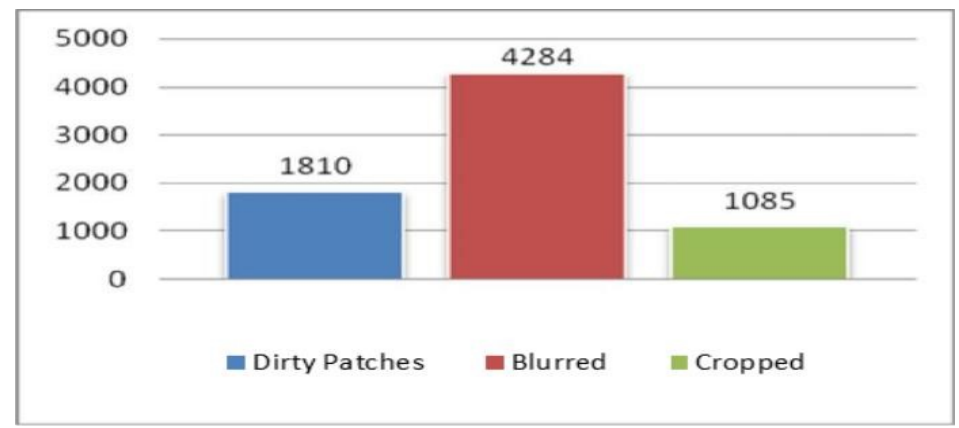

Fig. 2. Histogram of Radar Banten Newspaper Defects Product January 2013

d. Source: Secondary data were processed, 2013

In January, the most dominant types of defects caused blurred ink. The average defect caused blurred ink was 148 copies or $59.7 \%$ from total newspaper defects. The average for the dirty paper and cropped are 63 copies or $25.2 \%$ and 37 copies or $15.1 \%$, less than the average number and percentage of newspaper caused by blurred ink. In addition the percentage of defects in January is $1.09 \%$ from total production or products are checked for the month.

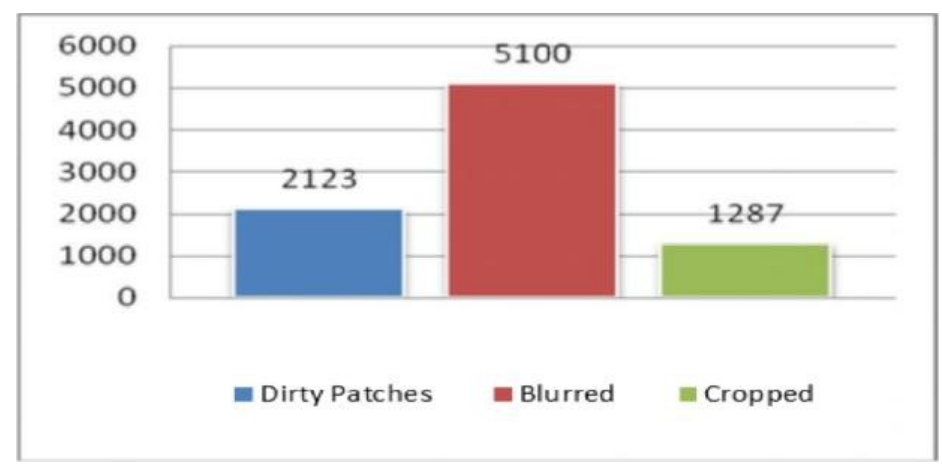

e. Source: Secondary data were processed, 2013

Fig. 3. Histogram of Radar Banten Newspaper Defects Product February 2013

In February, the most dominant type of defect is still caused by ink blur. The average defect caused blurred ink in February was 189 copies or $59.9 \%$, increasing 41 copies of the average defects in January. While the average for the dirty paper and cropped are 79 copies or $25 \%$ and 48 copies or $15.1 \%$, which also increased from January. But in the average and the percentage of defects is still lower than average and the percentage for blurred ink newspaper. Percentage of defects in February is $1.36 \%$ from total production for the month and increase $0.27 \%$ from January.

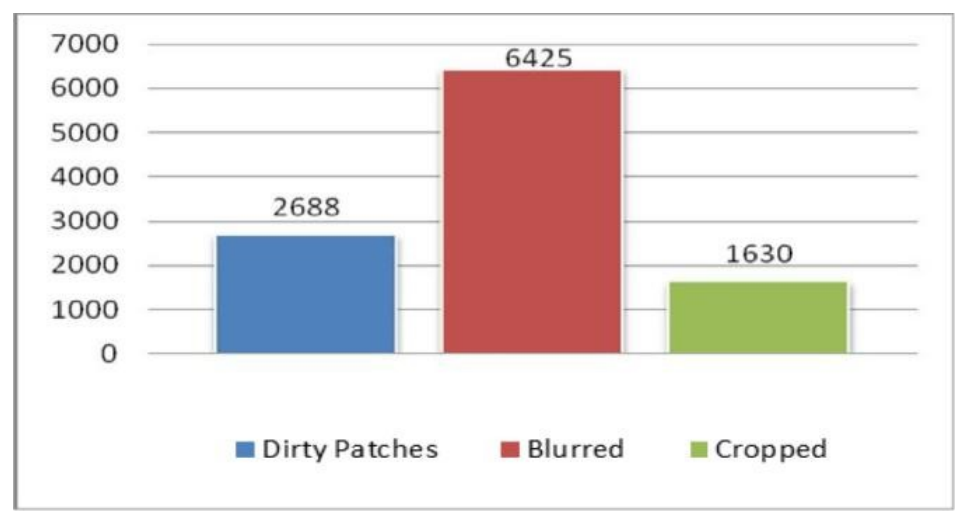

Fig. 4. Histogram of Radar Banten Newspaper Defects Product March 2013

Similarly with the conditions in January and February, the type of most dominant defect newspaper in March was caused by ink blur. Even in March the number is decreasing, with the average of newspapers defects caused blurred ink is 214 copies or $59.81 \%$. The type of dirty paper and cropped f. Source: Secondary data were processed, 2013

also increased by an average of defects and defect percentage around 90 and 54 copies or $25.02 \%$ and $15.17 \%$. The percentage of defects in March is $1.34 \%$ from total production in that month, decrease $0.02 \%$ from the month of February. 


\section{Arionse PRESS}

Based on histogram from January to March 2013 above, the type of most defect products is caused by blurred ink. The number of newspaper blurred was increase in every month likewise with dirty newspapers and cropped paper, but the number with blurred ink is the most dominant defect. Total defect of newspaper in January is 7.179 copies from 659.934, 8.519 from 624.975 copies in February and 10.743 from 805.470 copies. In addition the percentage of defects has increased every month, with the percentage of defect products in January is $1.09 \% \quad 0.27 \%$ increase in February became only $1.36 \%$ and decreases of $0.02 \%$ in March became $1.34 \%$.

After creating a histogram, next step is to create a p-chart or control chart, which the function to see the company quality control position. The steps in create a map of the control is as follows.

\section{A. Calculating percentage of defects}

Table IV. Total Production, Product Defects and Defects Product Percentage Radar Banten Newspapers January - March 2013

\begin{tabular}{|c|c|c|c|c|c|c|c|c|c|}
\hline \multirow{3}{*}{ Date } & \multicolumn{3}{|c|}{ January 2013} & \multicolumn{3}{|c|}{ February 2013} & \multicolumn{3}{|c|}{ March 2013} \\
\hline & $\begin{array}{c}\text { Total } \\
\text { (Copy) }\end{array}$ & $\begin{array}{c}\text { Total } \\
\text { Defects }\end{array}$ & & & $\begin{array}{c}\text { Total } \\
\text { Defects }\end{array}$ & & & $\begin{array}{c}\text { Total } \\
\text { Defects }\end{array}$ & Defect \\
\hline & & (Copy) & & (Copy) & (Copy) & & (Copy) & (Copy) & $(\%)$ \\
\hline 1 & 0 & 0 & 0 & 20760 & 251 & 1.21 & 34400 & 286 & 0.83 \\
\hline 2 & 20516 & 201 & 0.98 & 29923 & 311 & 1.04 & 29544 & 260 & 0.88 \\
\hline 3 & 20500 & 250 & 1.22 & 15070 & 25 & 0.17 & 15060 & 325 & 2.16 \\
\hline 4 & 20330 & 202 & 0.99 & 20948 & 71 & 0.34 & 30630 & 331 & 1.08 \\
\hline 5 & 29430 & 157 & 0.53 & 31094 & 350 & 1.13 & 30805 & 300 & 0.97 \\
\hline 6 & 15090 & 125 & 0.83 & 20722 & 451 & 2.18 & 30946 & 380 & 1.23 \\
\hline 7 & 20645 & 203 & 0.98 & 20690 & 330 & 1.59 & 20740 & 360 & 1.74 \\
\hline 8 & 20824 & 250 & 1.2 & 22915 & 220 & 0.96 & 30835 & 397 & 1.29 \\
\hline 9 & 20910 & 208 & 0.99 & 19860 & 280 & 1.41 & 29865 & 571 & 1.91 \\
\hline 10 & 20855 & 351 & 1.68 & 0 & 0 & 0 & 14857 & 351 & 2.36 \\
\hline 11 & 20885 & 200 & 0.96 & 31340 & 217 & 0.69 & 25830 & 280 & 1.08 \\
\hline 12 & 20359 & 255 & 1.25 & 20540 & 229 & 1.11 & 0 & 0 & 0 \\
\hline 13 & 15100 & 251 & 1.66 & 31193 & 311 & 1 & 31082 & 271 & 0.87 \\
\hline 14 & 31440 & 220 & 0.7 & 20995 & 391 & 1.86 & 31010 & 380 & 1.23 \\
\hline 15 & 31170 & 240 & 0.77 & 20776 & 320 & 1.54 & 31035 & 520 & 1.68 \\
\hline 16 & 31145 & 204 & 0.66 & 29890 & 430 & 1.44 & 30200 & 331 & 1.1 \\
\hline 17 & 20859 & 260 & 1.25 & 14926 & 325 & 2.18 & 14860 & 288 & 1.94 \\
\hline 18 & 31163 & 200 & 0.64 & 20943 & 291 & 1.39 & 31179 & 305 & 0.98 \\
\hline 19 & 20250 & 280 & 1.38 & 20789 & 370 & 1.78 & 31264 & 450 & 1.44 \\
\hline 20 & 15080 & 250 & 1.66 & 20888 & 380 & 1.82 & 31090 & 391 & 1.26 \\
\hline 21 & 31013 & 314 & 1.01 & 31067 & 420 & 1.35 & 31228 & 318 & 1.02 \\
\hline 22 & 31320 & 204 & 0.65 & 31036 & 446 & 1.44 & 32970 & 382 & 1.16 \\
\hline 23 & 20916 & 330 & 1.58 & 19869 & 550 & 2.77 & 30028 & 372 & 1.24 \\
\hline 24 & 0 & 0 & 0 & 15107 & 350 & 2.32 & 14940 & 499 & 3.34 \\
\hline 25 & 20830 & 271 & 1.3 & 25798 & 299 & 1.16 & 31141 & 333 & 1.07 \\
\hline 26 & 20240 & 191 & 0.94 & 14745 & 249 & 1.69 & 31187 & 411 & 1.32 \\
\hline 27 & 15571 & 263 & 1.69 & 21905 & 360 & 1.64 & 32345 & 399 & 1.23 \\
\hline 28 & 20923 & 300 & 1.43 & 31186 & 292 & 0.94 & 31305 & 333 & 1.06 \\
\hline 29 & 31030 & 351 & 1.13 & & & & 0 & 0 & 0 \\
\hline 30 & 20790 & 198 & 0.95 & & & & 30170 & 380 & 1.26 \\
\hline 31 & 20750 & 450 & 2.17 & & & & 14924 & 539 & 3.61 \\
\hline Jumlah & 659934 & 7179 & & 624975 & 8519 & & 805470 & 10743 & \\
\hline
\end{tabular}

\section{B. Calculating Central Line (CL)}

Central Line is the middle line between the upper control limit (UCL) and lower control limit (LCL). The center line is a line that represents the average defect rate in a production process. To calculate the center lines use the formula:

$$
\text { Annotation: } \mathrm{CL}=\overline{\mathrm{p}}=\frac{\sum n p}{\sum n}
$$

$$
\sum n p=\text { Total Defects }
$$

$\sum n=$ Total Information Obtained

$$
\text { h. Source: Heizer and Render, } 2005 .
$$

TABLE V. TOTAL NUMBER OF DEFECTS, TOTAL NUMBER INSPECTED, CENTRAL Line (CL) RADAR BANTEN JANUARY - MARCH 2013

\begin{tabular}{|c|c|c|c|}
\hline Month & $\sum_{n p}$ & $\sum_{n}$ & Central Line \\
\hline January 2013 & 7179 & 659934 & 0.011 \\
\hline February 2013 & 8519 & 624975 & 0.014 \\
\hline March 2014 & 10743 & 805470 & 0.013 \\
\hline
\end{tabular}

i. Source: Secondary data were processed, 2013

\section{Calculating Upper Control Limit (UCL)}

To calculate upper control limit performed by the formula:

$$
\mathrm{UCL}=\overline{\mathrm{p}}+3\left(\sqrt{\frac{\bar{p}(1-\overline{\mathrm{p}})}{\mathrm{n}}}\right)
$$

Annotation:

$\bar{p}=$ product defects average / central line

$\mathrm{n}=$ size of each sample

$$
\text { j. Source: Heizer and Render, } 2005 .
$$

\section{1) January 2013}

Subgroup 1: UCL $=\bar{p}+3\left(\sqrt{\frac{\overline{\theta(1-\overline{5}}}{\mathrm{n}}}\right)=0.11+3\left(\frac{0.121(1-2.212)}{208210}\right)=0.013$

Subgroup 2: UCL $=\bar{p}+3\left(\sqrt{\frac{\overline{3(1-\overline{5}}}{\mathrm{n}}}\right)=0.11+3\left(\frac{0.12(12-2.122)}{20500}\right)=0.013$

Subgroup 3: UCL $=\bar{p}+3\left(\sqrt{\frac{\overline{3(1-\overline{5}}}{\mathrm{n}}}\right)=0.11+3\left(\frac{0.121(1-2.212)}{201210}\right)=0.013$

And so on

\section{2) February 2013}

Subgroup 1: UCL $=\bar{p}+3\left(\sqrt{\frac{3(1-\overline{5}}{n}}\right)=0.11+3\left(\frac{0.12(12-2.212)}{20700}\right)=0.016$

Subgroup 2: UCL $=\bar{p}+3\left(\sqrt{\frac{\sqrt{\frac{(12-\bar{\nabla}}{n}}}{n}}\right)=0.11+3\left(\frac{0.121(1-2.212)}{2 \operatorname{cov2z}}\right)=0.016$

Subgroup 3: UCL $=\bar{p}+3\left(\sqrt{\frac{\overline{3(1-\overline{5}}}{\mathrm{n}}}\right)=0.11+3\left(\frac{0.12(12-2.212)}{15070}\right)=0.016$

And so on

3) March 2013

Subgroup 1: UCL $=\bar{p}+3\left(\sqrt{\frac{\sqrt{\frac{(12-\overline{5}}{n}}}{n}}\right)=0.11+3\left(\frac{0.121(1-2.212)}{14400}\right)=0.015$

Subgroup 2: UCL $=\bar{F}+3\left(\sqrt{\frac{3(12-\overline{5}}{n}}\right)=0.11+3\left(\frac{0.12(12-2.212)}{28: 44}\right)=0.015$

Subgroup 3: UCL $=\bar{p}+3\left(\sqrt{\frac{\overline{3(1-\overline{5}}}{\mathrm{n}}}\right)=0.11+3\left(\frac{0.12(12-0.212)}{15000}\right)=0.015$

And so on 


\section{$\triangle$ ATLANTIS PRESS}

\section{Calculating Lower Control Limit (LCL)}

To calculate the lower control limit or LCL performed by the formula:

$$
\begin{aligned}
& \quad \mathrm{LCL}=\overline{\mathrm{p}}-3\left(\sqrt{\frac{\overline{\mathrm{p}}(1-\overline{\mathrm{p}})}{\mathrm{n}}}\right) \\
& \text { Annotation: } \\
& \bar{p}=\text { product defects average } / \text { central line } \\
& \mathrm{n}=\text { size of each sample }
\end{aligned}
$$

k. Source: Heizer and Render, 2005.

\section{1) January 2013}

Subgroup 1: LCL $=\bar{p}-3\left(\sqrt{\frac{\sqrt{\frac{(1-\overline{5})}{a}}}{\pi}}\right)=0.11+3\left(\frac{0.12(1-0.12)}{20520}\right)=0.09$

Subgroup 2: LCL $=\bar{p}-3\left(\sqrt{\frac{\sqrt{5(1-\bar{D})}}{n}}\right)=0.11+3\left(\frac{0.12(1-0.12)}{20500}\right)=0.09$

Subgroup 3: LCL $=\bar{p}-3\left(\sqrt{\frac{\sqrt{5(1-\bar{D})}}{\pi}}\right)=0.11+3\left(\frac{0.12(1-0.12)}{20120}\right)=0.09$ And so on

\section{2) February 2013}

Subgroup 1: LCL $=\bar{p}-3\left(\sqrt{\frac{\sqrt{(1-\bar{p}}}{n}}\right)=0.11+3\left(\frac{0.11(1-0.12)}{20700}\right)=0.011$

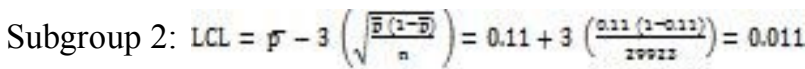

Subgroup 3: LCL $=\bar{p}-3\left(\sqrt{\frac{\sqrt{(1-\bar{p})}}{n}}\right)=0.11+3\left(\frac{0.12(1-0.22)}{125070}\right)=0.011$

And so on

3) March 2013

Subgroup 1: LCL $=\bar{p}-3\left(\sqrt{\frac{\sqrt{5(1-\bar{p}}}{n}}\right)=0.11+3\left(\frac{0.12(1-0.212)}{24450}\right)=0.011$

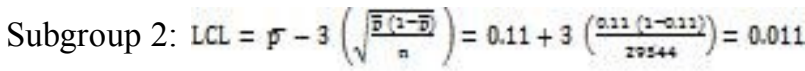

Subgroup 3: LCL $=\bar{p}-3\left(\sqrt{\frac{\overline{(12-\bar{s}}}{a}}\right)=0.11+3\left(\frac{0.12(1-0.12)}{15000}\right)=0.011$

And so on

From the calculation above, we can make a p-chart using Microsoft excel 2007 which can be seen in figure below:

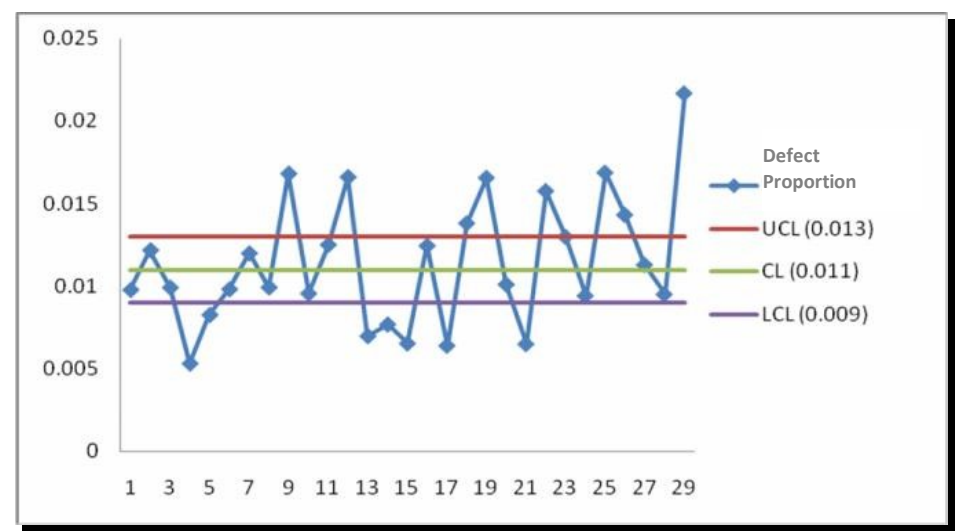

Fig. 5. P-Chart of Radar Banten Newspaper Proportion Defects January 2013

In January there are 8 points above the line of upper control limit (UCL) and 7 points under the line of lower control limit (LCL). From 29 points, there are 8 points above the line of upper control limit (UCL), its means $27.6 \%$ defect products is over from tolerable limits. The $24.1 \%$ defect under LCL line indicates the proportion of small defect. While 14 points or $48.3 \%$ still in line between LCL and UCL, indicating defect is still in tolerance.

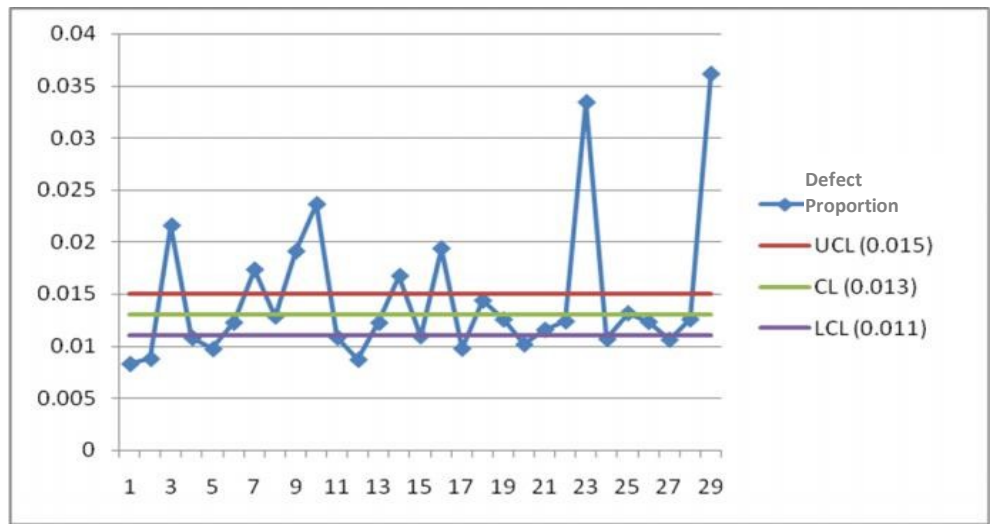

Fig. 6. P-Chart of Radar Banten Newspaper Proportion Defects February 2013

Above is P-Chart in February, there are 9 from 27 points are above the line of upper control limit (UCL). Its means
$33.3 \%$ defect is over from tolerable limits. Meanwhile, $26 \%$ defect under LCL line indicates the proportion of small defect. $40.7 \%$ defect is still inline between UCL and LCL control 
limits or 11 point is indicates the number of defects that over the control limit are increase from January. The percentage of defect that over the control limit is increased 5.7\% from
January. This indicates the control or supervision of the quality declined from the previous month.

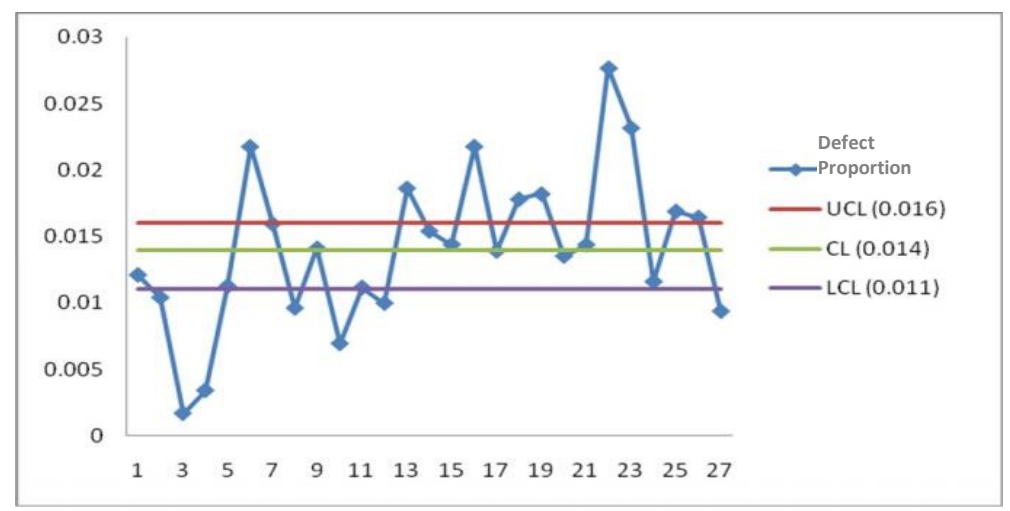

Fig. 7. P-Chart of Radar Banten Newspaper Proportion Defects March 2013

In March, the point that over the control limit is 8 points from 29 points. Its mean $27.6 \%$ defect over the control limit. $34.5 \%$ or 10 points under the line LCL and $37.9 \%$ or 11 points defect still in control of the boundary area or still between UCL and LCL line. This condition shows declining condition from January until March. In January defect are still in line of UCL and LCL is $48.3 \%$ that decrease in February become 40.7\% and more decrease become $37.9 \%$ in March.

From three control maps above, we can see that the defect newspapers over the control limit still fluctuate each month. The fluctuating number of defect product above UCL shows inconsistency quality control of product in PT. Wahana Java Semesta Intermedia. Because of that PT. Wahana Java Semesta Intermedia need a better quality control system. In January $27.6 \%$ defect is over the control limit and then increased to $33.3 \%$ in February. However, for the month of March, the defect is above UCL line decrease to $27.6 \%$ but still biggest than the percentage of decline in January. In addition, in January there is one point outlier then increased in February and March become 2 points outlier. Outlier point is higher point then the other is because of the defect number and the percentage of defect is high on that day. This p- chart result was seen the number of points that are above the upper limit is still fluctuating, rising in February and declined in
March. Moreover, with increasing outlier points that are outside the UCL line indicates declining activities in quality control and this condition need more attention.

Causal diagram or Fishbone diagram was made after the $\mathrm{p}$ chart to analyze the factors that become the cause of product defects. The factors that influence and cause defect products can generally be classified as:

- Man, i.e. workers in the production process.

- Material, i.e. the components in producing products into finished goods.

- Machine, i.e. equipment used during the production process.

- Method, i.e. instructions or work orders to be followed in the production process.

- Environment, i.e. the circumstances around the production site, which directly or indirectly affect the production process.

We can see from histogram in figure 2 until figure 4 that there are three types of defect product in the production process are dirty paper, ink blur, and cropped paper. As a tool to find the cause of the defect, fishbone diagram is used to explore each type of defects. Here is a causal diagram use for dirty paper, ink blur, and cropped paper.

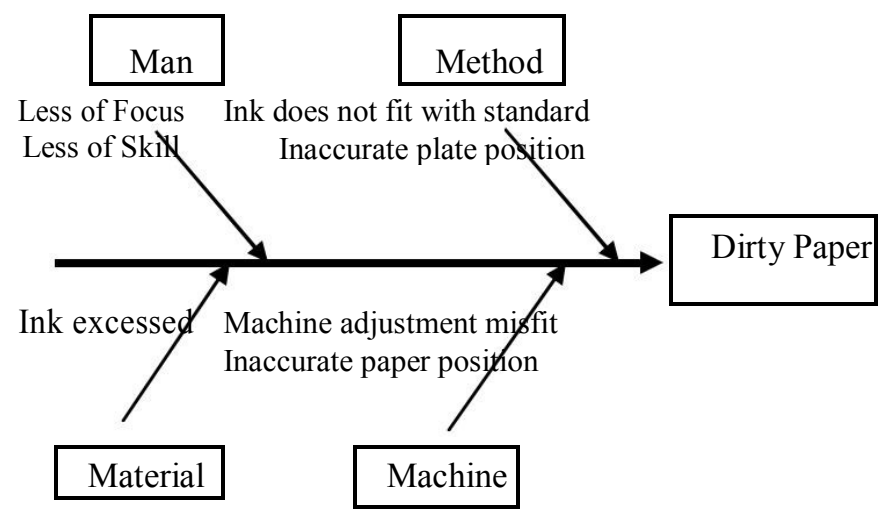

${ }^{\text {o. }}$ Source: Secondary data were processed, 2013

Fig. 8. Fishbone diagram of Dirty Newspapers 
Newspapers were dirty it caused by poor ink absorption, ink too fluid and the ink too much which caused the product is not worthy to published. This usually because of the ink on the printing is too much and liquid, causing some printouts are inkblots. In addition, other factors that caused the paper become dirty is the position of the paper and printing plates does not fit caused by workers who are less focused. Setting machines that do not fit well also caused the prints are ink blots and dirty.

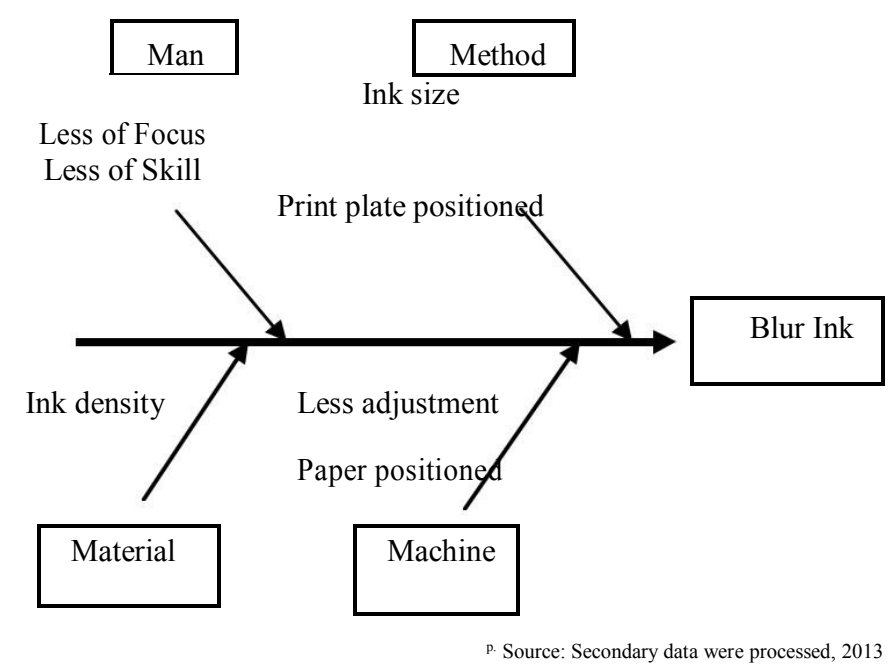

Fig. 9. Fishbone diagram of Blurred Ink Diagram

Printing results with blurred ink caused by the absorption of the ink are not doing well, because of that blurred ink product is considered not worthy to publish. This usually occurs at the start of printing, because at the beginning of printing ink on the printing machine is still concentrated (not too liquid) that caused some printouts look blurry. In addition, other factors that caused this problem that ink is not fit caused by workers who are less focused. Machines adjustment that not fit also caused blurred prints.



q. Source: Secondary data were processed, 2013

Fig. 10. Fishbone diagram of Blurred Ink Diagram

Cropped newspapers which does not fit with the layout during the cutting process by the machine then there are inaccurately text or picture, caused by less careful operator while checking machine adjustment or checking the sharpness of the cutting blade. Employee's less of careful also caused by hot room temperatures from the machine. Moreover lack of coordination between operators also cause the disrupted of machine adjustment.

\section{Conclusion}

\section{CONCLUSIONS}

- Quality Control

Based on the histogram, the highest defect for 3 months is caused blurred ink with $59.79 \%$ and defect caused by dirty paper with a percentage of $25.07 \%$. Defect caused as newspapers cropped is not on part with $15.14 \%$ percentage of defects. The percentage of defects inspected by total production is $1.26 \%$. Based on the results of the control map (p-chart) can be seen that the quality control is over the control limit. This can be seen in the control chart that shows there are many points that are over the control limit, the point is fluctuating. In January, $27.6 \%$ defect is over the control limit and increased to $33.3 \%$ in February decreased to $27.6 \%$ in March.

- Based on the fishbone diagram we can see the factors that cause in the quality control are man, machine, work methods, materials and work environment. Where is the 
biggest cause factor caused by man or workers who are less focused or less skilled.

\section{REFERENCES}

[1] Jukka Rantamäki Eeva-Liisa Tiainen Tuomo Kässi. 2013. "A case of implementing SPC in a pulp mill", International Journal of Lean Six Sigma, Vol. 4 Iss 3 pp. $321-337$.

[2] B.L. MacCarthy Thananya Wasusri. 2002. "A review of non-standard applications of statistical process control (SPC) charts", International Journal of Quality \& Reliability Management, Vol. 19 Iss 3 pp. 295 320.

[3] Nurhasanah, N dan Diah Safitri. 2010. "Komponen Utama Pengendalian Kualitas Secara Statistik". Semarang: UNDIP

[4] Able, M. Charles. et. Al. 2011. "Initial investigation using statistical process control for quality control of accelerator beam steering". Radiation Oncology 2011, 6:180 http://www.rojournal.com/content/6/1/180.

[5] Rajiv Sharma Manjeet Kharub. 2014. "Attaining competitive positioning through SPC - an experimental investigation from SME", Measuring Business Excellence, Vol. 18 Iss 4 pp. $86-103$.

[6] Fakhri, Faiz A. 2010. "Analisis Pengendalian Kualitas Produksi di PT. Masscom Graphy Dalam Upaya Mengendalikan Tingkat Kecacatan Produk Menggunakan Alat Bantu Statistik". Semarang: UNDIP

[7] Heizer, Jay dan Barry Render. 2005. Operations Management Buku 1. Jakarta: Salemba Empat.

[8] Ferdinand, Augusty. 2011. Metode Penelitian Manajemen. Semarang: BP UNDIP

[9] Joyce Chapman David Woodbury. 2012. "Leveraging quantitative data to improve a device-lending program", Library Hi Tech, Vol. 30 Iss 2 pp. $210-234$. 